\title{
Angioimmunoblastic T-Cell Lymphoma by Ann Arbor Stage
}

National Cancer Institute

\section{Source}

National Cancer Institute. Angioimmunoblastic T-Cell Lymphoma by Ann Arbor Stage. NCl Thesaurus. Code C141294.

An anatomic stage for angioimmunoblastic T-cell lymphoma based on the Ann Arbor classification criteria. 